Jap. J. M. Sc. \& Biol., 11, 59-71, 1958

\title{
INFECTION OF THE ONE-DAY OLD FERTILE HEN'S EGG WITH RABIES VIRUS

\author{
V. CULTIVATION OF DIFFERENT STRAINS IN THE EGG-WHITE \\ REPLACED ONE-DAY EGG (ERO) WITH SPECIAL REFERENCE \\ TO INTERFERENCE BETWEEN ADULT-MOUSE-PATHOGENIC \\ AND NON-PATHOGENIC STRAINS
}

\author{
Kamesaburo YOSHINO, AkIRa KONDO, Nobuaki KUMA \\ AND MASAMI KITAOKA \\ Department of Virology \& Rickettsiology, National Institute of Health, Tokyo
}

(Received: February 18th, 1958)

\begin{abstract}
Rabies virus has been known as one of the most cumbersome viruses in the attempts of in vitro cultivation. Kanazawa (1936) first succeeded in growing a fixed rabies strain in tissue culture with rabbit embryo brain, and similar results were obtained by Webster and Clow (1936), Webster (1937), Bernkopf and Kligler (1937), Schultz and Williams (1937-8) and Parker and Hollender (1945) using mouse embryo brain. Plotz and Reagan (1942) also passed two street virus strains in tissue culture employing whole chick embryo. However, no convincing evidence has ever been presented for success in cultivation of this virus without recourse to nervous tissues, despite the remarkable progress of tissue culture techniques during the last decade. Besides, the culture fluid in the above successful cases generally showed only low levels of viral yield, and reproducibility of those results seemed to vary greatly among different strains (Kanazawa, personal communication).

Recently, Bequignon and coworkers (1954) observed maintenance over a period of 65 days of rabbit-fixed Pasteur strain in roller tube cultures employing mouse embryo brain, and stated that the fibroblastic outgrowth seemed to produce virus without showing any cytopathic changes. Unfortunately, however, these results could not be reproduced in our hands with our mouse-fixed strains, nor with their street virus (Vienchange et al., 1956). Also recently, Kanazawa (personal communication) could pass egg-adapted Nishigahara strain in tissue culture with chick embryo cells, but fairly luxuriant virus growth was seen only in the first few passages. With the same technique, however, we could not obtain any growth of the egg-adapted Flury strain. Thus, a time has not yet come when tissue culture virus can be commonly used as a source of vaccine, although earlier data given by Webster and Clow (1936), Kligler and Bernkopf (1938) and Webster (1938) cast promissing light on such practical application of culture virus.
\end{abstract}

吉野亀三郎・近藤昭・久間信章・北岡正見（国立予防衛生研究所リケッチアウィルス部） 
In the meantime, it was found here that two strains of rabies virus, mouse-fixed CVS and early egg passage of Flury, could readily grow in 1-day eggs (Yoshino et al., 1956a) and that adult-mouse-non-pathogenic HEP (high egg passage) rabies viruses were rather more infective to 1-day eggs (Kuma, 1958). These discoveries, coupled by the information that the 1-day egg whose egg-white was replaced with saline could serve as a new type of tissue culture for herpes simplex virus (Yoshino and Taniguchi, 1957), led the authors to the attempt to cultivate the above strains of rabies virus in the egg-white-replaced 1-day egg (ERO), with the result that sufficient growth in the blastodermal tissues as well as release into saline of these viruses was observed. In addition, 1-day egg-adapted lines of these strains produced by serial 1-day egg passage were also grown in this culture system in comparison with their respective mother strains. Of course, the present ERO culture method is by no means perfectly satisfactory, but the results to be reported will suggest that the ERO is applicable not only for the practical purposes such as vaccine production but also for some theoretical studies of the host-virus interactions.

\section{Materials ANd Methods}

Viruses: The mouse-fixed CVS strain was used as 73rd to 84th mouse brain passages, and its 1-day egg-adapted line COP as 44th 1-day egg passage. The early egg passage of Flury still pathogenic for adult mice was used as 128th to 130th 7-day egg passage, and its 1-day eggadapted line FOP as 40th 1-day egg passage. Methods of serial passage and seed preparation of these viruses were stated previously (Yoshino et al., $1956 \mathrm{a}$ ). In addition, two HEP rabies strains, HEP Flury and HEP Nishigahara (Kuma, 1958), were also passed in 1-day eggs in a mode similar to that adopted for CVS and Flury (Yoshino et al., $1956 \mathrm{a}$ ) and the resulting 1-day egg-adapted lines of these strains were called HEP Flury-OP (or HFOP) and HEP NishigaharaOP (or HNOH), respectively. The 1-day egg passage of the HEP strains did not change their animal pathogenicities. The 211th to 213th 7-day egg passages of HEP Flury, 8th to 25th 1-day egg passages of HEP Flury-OP, 293rd to 294th 7-day egg passages of HEP Nishigahara and 17th to 21st 1-day egg passages of HEP Nishigahara-OP viruses were employed in the present work.

ERO (egg-white-replaced 1-day egg) technique: The original method (Yoshino, 1956) was improved later (Yoshino and Taniguchi, 1957). The present techniques were essentially the same as those except that the saline contained Mycostatin (Squibb \& Co., U. S. A.) in addition to penicillin and streptomycin. Namely, 1-day eggs were first candled to eliminate eggs showing no dark point (blastodermal center) in the center of yolk shadow, and the fertile eggs thus selected were placed in a horizontal position. A slit and a circular groove surrounding it with a diameter of approximately $10 \mathrm{~mm}$ were made in shell with a rotating carborundum disc with the precaution not to cut shell membrane, and an air-hole was opened over the air sac. Then, a ring of paraffin-vaseline mixture (1:2 by weight) was mounted on shell slightly outside of the circular cut. For inoculation, each egg was candled in a dark room after washing shell surface with alcohol sponge, rotated gently until the blastodermal center was located at a point about $5 \mathrm{~mm}$ distant from the slit, and then a $7 \mathrm{~mm}$ needle attached to a syringe was shot through the slit to introduce an inoculum of $0.2 \mathrm{cc}$ amount into the yolk sac. When the material to be injected had been cooled, it was warmed quickly in a $35^{\circ} \mathrm{C}$ water bath just prior to this step. This inoculation procedure was illustrated before (Yoshino et al., $1956 \mathrm{~b})$. On completion of the injection, the air-hole was sealed with paraffin-vaseline, and the eggs were placed in a $35^{\circ} \mathrm{C}$ incubator with the slit down in order to avoid fixation of the blastoderm to shell. After 3 hours, the eggs were removed out of the incubator and turned 
again to regain the former position. Then, the shell disc inside the paraffin-vaseline ring was removed together with shell membrane adhering to it, egg-white dumped out, $20 \mathrm{cc}$ of saline containing $0.01 \mathrm{M}$ phosphate buffer of $\mathrm{pH} 7.6,500 \mathrm{u} / \mathrm{cc}$ of penicillin, $100 \mu \mathrm{g} / \mathrm{cc}$ of streptomycin and $20 \mathrm{u} / \mathrm{cc}$ of Mycostatin added into the emptied cavity, a flame-heated cover slip placed on the paraffin-vaseline ring, and further incubation performed at $35^{\circ} \mathrm{C}$. At intervals thereafter, a sample of 3 to 5 ERO's showing clearly transparent saline was randomly selected, aliquots of saline from parallel ERO's were pooled, and their yolks were homogenized with the addition of an equal volume of buffered saline. Each material was tested for bacterial contamination using thioglycollate medium, and titrated in adult mice and in 1-day eggs in the manner previously stated (Kuma, 1958). Titers were expressed as total MIU (adult mouse infective units) and/or OIU (1-day egg infective units) contained in the yolk (averaging $18 \mathrm{cc}$ per egg) and in the saline $(20 \mathrm{cc}$ per egg) portions, and called yolk virus and saline virus, respectively.

MIU (mouse-infective unit) determination: Only adult mice (GPC strain of Swiss mice) 4 to 5 weeks old were used. Titration method and calculation of MIU were stated previously (Kuma, 1958). Thus, in this work, MIU refers to adult mouse LD unit.

OIU (1-day egg-infective unit) determination: This was also detailed previously (Kuma, 1958). For all the strains tested, incubation of inoculated 1-day eggs was done for one week following inoculation.

Other details of methods are to be referred to the preceding papers (Kuma, 1958; Kondo, 1958).

\section{RESULTS}

\section{Growth Curves of Different Strains of Rabies Virus in the ERO}

The four mother strains, (1) mouse-fixed CVS, (2) early 7-day egg passage of Flury, (3) HEP Flury and (4) HEP Nishigahara, and their 1-day egg passage lines, ( $\left.1^{\prime}\right) \mathrm{COP},\left(2^{\prime}\right)$ FOP, ( $\left.3^{\prime}\right)$ HEP Flury-OP (HFOP) and $\left(4^{\prime}\right)$ HEP Nishigahara-OP (HNOP), were given to 1-day eggs, from which ERO's were prepared as stated under Methods, and with daily intervals yolk and saline virus titers were examined. With some of these strains, two experiments were performed using seeds of similar strengths, which revealed that the results were highly reproducible.

Gross appearance of blastoderms following infection did not differ greatly from what was observed in the case of herpetic infection of the ERO (Yoshino and Taniguchi, 1957); the blastoderm continuously expanded over the surface of yolk sac while development of the embryo was markedly restricted. However, unlike the case of herpes infection, the ERO's occasionally showed formation of blood vessels and a certain degree of embryonic enlargement, frequency of such cases being fewer with the 1-day egg-adapted lines than with their mother strains.

The titration results are plotted in Fig. 1, in which some curves express geometric means from two experiments exhibiting quite similar values. These experiments were planned with a special care so as to use a similar height of seed virus for each combination of a mother strain and its 1-day egg passage line. Thus, in the experiments with CVS and COP viruses, approximately $10^{4} \mathrm{MIU}$ was introduced per egg (A, Fig. 1). The previous data warranting the use of MIU as a common measuring unit for CVS and COP viruses (Kondo, 1958) permitted fair comparison between these two growth curves. It can be seen that $\mathrm{COP}$ virus multiplied much faster than CVS and the peak titer was slightly higher with COP than with CVS infection. Namely, CVS curve rose from the 3rd or 4th day and reached peak titer around the 7 th day both in yolk and in saline portions, whereas 


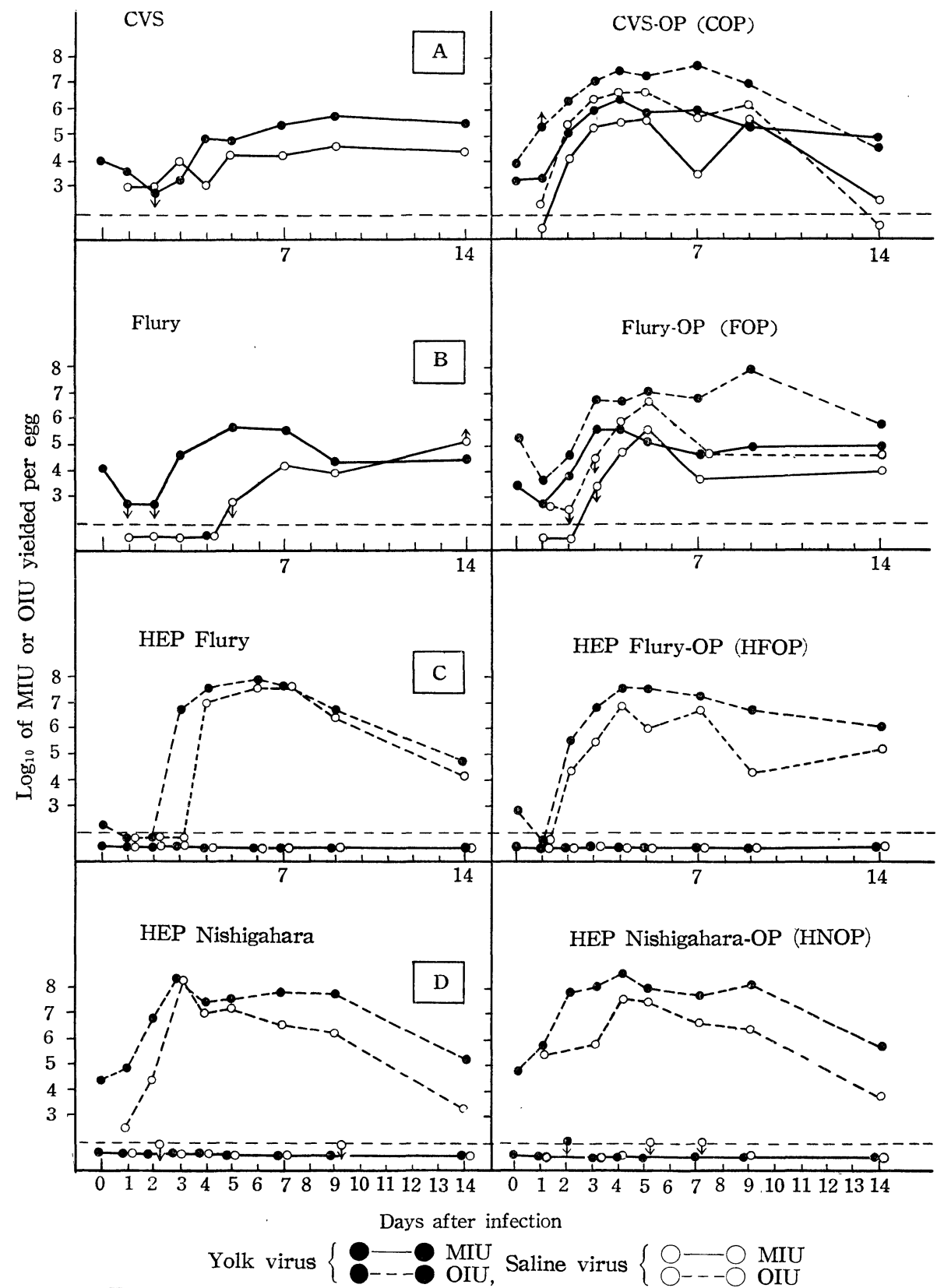

Fig. 1. Growth curves of different strains of rabies virus in the ERO.

COP curve showed a marked rise already 2 days after infection and reached peak around the 4th day. A similar trend was observed in the comparison between Flury and FOP growth curves (B, Fig. 2); i.e. growth of FOP virus was more rapid than that of Flury virus, but this time the peak titers were on the same level between the two viruses. 
With HEP Flury and HEP Flury-OP (HFOP) viruses, about $10^{2}$ OIU was given per egg, and in the case of HEP Flury virus high titers of virus were seen in 3 and 4 days following infection in yolk and saline, respectively, but in the case of HFOP detectable level of virus first appeared in both portions on the 2nd day (C, Fig. 1). This may imply that the HEP Flury strain, after converted to HFOP through 1-day egg passage, had become more adapted to this host. However, the difference between HEP Flury and HFOP was far less conspicuous than that between CVS and COP or that between Flury and FOP, because the 3rd and 4th day titers of HFP Flury curve exceeded the corresponding titers of HFOP curve. In these two experiments, no test material could kill any adult mouse in the parallel mouse titration. The results with HEP Nishigahara and HEP Nishigahara-OP (HNOP) viruses disclosed more or less the same trends as observed in the preceding two experiments, in that the curves differed only slightly between these two viruses (D, Fig. 1).

Comparison of the peak titers reached by all these strains needs special consideration, because two of them (CVS and Flury) could be expressed only by MIU and the HEP group viruses could be titrated only by 1-day eggs. The other two (COP and FOP) revealed their titers both in MIU and in OIU, which differed by approximately one log. The quantitative analysis of MIU and OIU of these strains previously performed (Kondo, 1958) justified the use of baby mouse infective unit as a common measuring unit for all of them. It was also found that, in the cases of HEP group viruses, baby mouse infective unit equalled OIU (Kuma, 1958), and that this was also the case with COP virus (Kondo 1958). In the present results, the peak titers in the growth curves of COP, FOP and HEP group viruses were on the same level in OIU, therefore it may be concluded that all the viruses here tested yielded more or less the same quantities of virus in this culture system, except CVS strain which showed but slightly lower level of virus.

\section{Simultaneous Inoculation with CVS and HFOP Viruses}

Koprowski et al. (1954) demonstrated that their HEP Flury virus interfered with the growth of earlier egg passage of Flury in the adult mouse brain but failed to do so with rodent-fixed strains. Such interference between adult-mouse-pathogenic and non-pathogenic rabies viruses was thought to be better shown in the present culture system. The quantitative analyses of the ERO infection with herpes simplex virus (Yoshino and Taniguchi, 1957) estimated the total number of susceptible entodermal cells in the ERO at $2.5 \times 10^{5}$, enabling exact quantitation between invading viral infective units and cells. Use was made, therefore, of this information in our present study to detect occurrence of interference among rabies strains.

First, undersaturating amounts, in terms of MIU or OIU per entodermal cell, of both CVS and HFOP viruses were simultaneously inoculated into 1-day eggs, and thereafter the eggs were treated in the same manner as in the preceding experiments, except that this time only saline virus was titrated (Exp. 1, Fig. 2). In view of the facts that the CVS virus can not kill all 1-day eggs within one week even when fairly massively inoculated (Yoshino et al., 1956a) and that the HFOP virus could not kill adult mice, it was considered to be a reasonable interpretation that the MIU and OIU titers of saline here obtained expressed the amounts of CVS and $\mathrm{HFOP}$ viruses, respectively. In this case, therefore, no interference took place. 
Then, it was tried in the next experiment to see if any interference would occur when the entodermal cells were added with nearly saturating doses of these two viruses (Exp. 2, Fig. 2). The result, however, was again negative, displaying similar growth curves of both viruses as was seen in Exp. 1.

Experiment 3 (Fig. 2) was then designed to observe the outcome of inoculation with approximately 1,000 times as much HFOP virus (in OIU) as the CVS virus (in MIU). With this HFOP : CVS ratio, adult mouse-killing virus was detected only in a small amount on the 3rd day but disappeared thereafter, while 1-day egg-killing virus increased just as abundantly as if it had been inoculated singly. These results clearly indicated that the CVS growth could be interfered with only by the addition of a sufficiently excessive amount of HFOP virus.

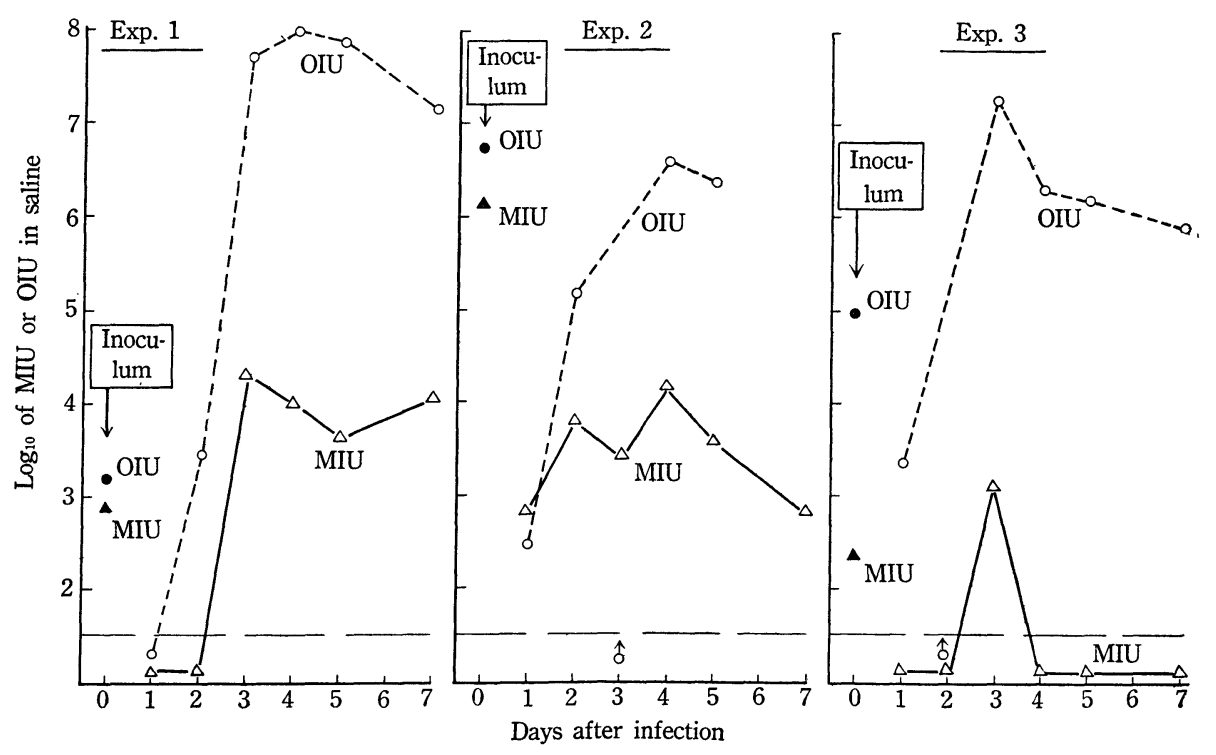

Fig. 2. Titration of saline virus of ERO after simultaneous inoculation with CVS (adult-mouse-pathogenic) and HFOP (adult-mouse-non-pathogenic) viruses.

The next search was made to find the minimum interfering HFOP : CVS ratio, giving simultaneously a small amount of CVS together with graded concentrations of HFOP virus or control horse-serum saline. This time, the ERO's were examined only for MIU titers of saline virus 5 days following infection (Exp. 1, Table 1). It was demonstrated that 2,000 OIU of HFOP virus could interfere with $700 \mathrm{MIU}$ of CVS virus; that is, the minimum interfering ratio was about $3: 1$ in terms of the former's OIU versus the latter's MIU. Since it was estimated previously (Kondo, 1958) that the adult mouse-infective titer of CVS virus was approximately 4 times higher than its 1-day egg-infective titer, actual minimal interfering ratio may be $12: 1$.

However, as can be seen in Table 1 , the group given 20 OIU of HFOP virus showed occurrence of interference. Such an irregularity at the limiting dilutions 
of the interfering virus was sometimes encountered in repeated experiments. Moreover, experiments of the same design did not invariably reproduce the abovegiven ratio between a given amount of CVS virus and the minimum interfering dose of HFOP virus, but this ratio calculated from this kind of experiment seemed to fluctuate within a wide range. Thus, it was felt that a strictly quantitative analysis of the result obtained by this method would be difficult. Nevertheless, it might be permitted to give a rough estimation that a slight excess of HFOP virus over CVS virus in amount is likely to induce interference with the latter.

A similar test was then performed using Flury (early egg passage) in place of CVS virus (Exp. 2, Table 1). The result indicated that about 100 times more HFOP than Flury was required to induce interference.

Table 1. Interference in the ERO by adult-mouse-non-pathogenic HFOP with CVS or Flury strain

\begin{tabular}{|c|c|c|c|c|c|c|c|}
\hline \multirow{2}{*}{ Exp. } & \multirow{2}{*}{\multicolumn{2}{|c|}{ Virus in inoculum }} & \multicolumn{4}{|c|}{$\begin{array}{l}\text { Dilution of pooled saline harvested } \\
5 \text { days after inoculation }\end{array}$} & \multirow{2}{*}{$\begin{array}{l}\text { Titer of adult } \\
\text { mouse killing } \\
\text { virus in saline }\end{array}$} \\
\hline & & & $10^{-0}$ & $10^{-1}$ & $10^{-2}$ & $10^{-3}$ & \\
\hline \multirow{9}{*}{1} & MIU & OIU & & & & & $\mathrm{MIU} / 20 \mathrm{cc}$ \\
\hline & CVS & HFOP & & & & & \\
\hline & $7.0 \times 10$ & ${ }^{2}+2.0 \times 10^{5}$ & $0 / 5^{*}$ & $0 / 5$ & $0 / 5$ & & 0 \\
\hline & $\prime \prime$ & $+2.0 \times 10^{4}$ & $0 / 5$ & $0 / 5$ & $0 / 5$ & & 0 \\
\hline & $\prime \prime$ & $+2.0 \times 10^{3}$ & $0 / 5$ & $0 / 5$ & $0 / 5$ & & 0 \\
\hline & $\prime \prime$ & $+2.0 \times 10^{2}$ & $5 / 5$ & $5 / 5$ & $1 / 5$ & & $4.3 \times 10^{3}$ \\
\hline & " & $+2.0 \times 10^{1}$ & $1 / 5$ & $0 / 5$ & $0 / 5$ & & $<4.3 \times 10^{1}$ \\
\hline & " & $+2.0 \times 10^{\circ}$ & $5 / 5$ & $4 / 5$ & $0 / 5$ & $0 / 5$ & $2.4 \times 10^{3}$ \\
\hline & $\prime \prime$ & + HSS $^{\#}$ & $5 / 5$ & $4 / 5$ & $4 / 5$ & $2 / 5$ & $3.5 \times 10^{4}$ \\
\hline \multirow{8}{*}{2} & Flury & HFOP & & & & & \\
\hline & $1.9 \times 10$ & ${ }^{2}+2.2 \times 10^{6}$ & $0 / 5$ & $0 / 5$ & $0 / 5$ & & 0 \\
\hline & $\prime \prime$ & $+2.2 \times 10^{5}$ & $0 / 5$ & $0 / 5$ & $1 / 5$ & & $<2.7 \times 10^{2}$ \\
\hline & " & $+2.2 \times 10^{4}$ & $1 / 5$ & $0 / 5$ & $0 / 5$ & & $<2.9 \times 10^{2}$ \\
\hline & $\prime \prime$ & $+2.2 \times 10^{3}$ & $5 / 5$ & $1 / 5$ & $0 / 5$ & & $2.9 \times 10^{3}$ \\
\hline & $\prime \prime$ & $+2.2 \times 10^{2}$ & $4 / 5$ & $0 / 5$ & $0 / 5$ & $0 / 5$ & $1.6 \times 10^{3}$ \\
\hline & $\prime \prime$ & $+2.2 \times 10^{1}$ & $4 / 5$ & $1 / 5$ & $0 / 5$ & $1 / 5$ & $2.9 \times 10^{3}$ \\
\hline & " & + HSS & $5 / 5$ & $1 / 5$ & $3 / 5$ & $0 / 5$ & $6.7 \times 10^{3}$ \\
\hline
\end{tabular}

* Numerator : Number of deaths among inoculated adult mice. Denominator : Total number inoculated.

\# Horse-serum saline.

Further studies were made on the interfering capacity of HNOP virus against CVS and Flury viruses. The HNOP virus itself was, as stated before (Kuma, 1958), not entirely deprived of the pathogenicity for adult mice but occasionally killed them. This point was a disadvantage of this virus when attempting to demonstrate its interfering capacity with adult-mouse-pathogenic viruses in the ERO. However, results of these experiments arranged in Table 2 indicate that 
Table 2. Interference in the ERO by adult-mouse-non-pathogenic HNOP with CVS or Flury strain

\begin{tabular}{|c|c|c|c|c|c|c|c|}
\hline \multirow{2}{*}{ Exp. } & \multirow{2}{*}{\multicolumn{2}{|c|}{ Virus in inoculum }} & \multicolumn{4}{|c|}{$\begin{array}{l}\text { Dilution of pooled saline harvested } \\
5 \text { days after inoculation }\end{array}$} & \multirow{2}{*}{$\begin{array}{l}\text { Titer of adult } \\
\text { mouse killing } \\
\text { virus in saline }\end{array}$} \\
\hline & & & $10^{-0}$ & $10^{-1}$ & $10^{-2}$ & $10^{-3}$ & \\
\hline \multirow{9}{*}{1} & MIU & OIU & & & & & $\mathrm{MIU} / 20 \mathrm{cc}$ \\
\hline & CVS & HNOP & & & & & \\
\hline & $4.9 \times 10^{1}$ & $+1.6 \times 10^{6}$ & $0 / 5^{*}$ & $1 / 5$ & $0 / 5$ & & $<2.7 \times 10^{2}$ \\
\hline & $\prime \prime$ & $+1.6 \times 10^{5}$ & $0 / 5$ & $0 / 5$ & $1 / 5$ & & $<2.7 \times 10^{2}$ \\
\hline & $\prime \prime$ & $+1.6 \times 10^{4}$ & $0 / 5$ & $0 / 5$ & $0 / 5$ & & 0 \\
\hline & $\prime \prime$ & $+1.6 \times 10^{3}$ & $0 / 5$ & $0 / 5$ & $0 / 5$ & & 0 \\
\hline & "I & $+1.6 \times 10^{2}$ & $2 / 5$ & $0 / 5$ & $0 / 5$ & & $<4.5 \times 10^{2}$ \\
\hline & "I & $+1.6 \times 10^{1}$ & $2 / 5$ & $0 / 5$ & $0 / 5$ & $0 / 5$ & $<4.5 \times 10^{2}$ \\
\hline & $\prime \prime$ & $+\mathrm{HSS}^{\#}$ & $5 / 5$ & $2 / 5$ & $0 / 5$ & $0 / 5$ & $4.5 \times 10^{3}$ \\
\hline \multirow{8}{*}{2} & Flury & HNOP & & & & & \\
\hline & $8.0 \times 10^{2}$ & $+1.2 \times 10^{7}$ & $0 / 5$ & $0 / 5$ & $0 / 5$ & & 0 \\
\hline & "I & $+1.2 \times 10^{6}$ & $0 / 5$ & $0 / 5$ & $0 / 5$ & & 0 \\
\hline & "I & $+1.2 \times 10^{5}$ & $1 / 5$ & $0 / 5$ & $1 / 4$ & & $<3.8 \times 10^{2}$ \\
\hline & $\prime \prime$ & $+1.2 \times 10^{4}$ & $0 / 5$ & $3 / 5$ & $3 / 5$ & & $2.3 \times 10^{3}$ \\
\hline & $\prime \prime$ & $+1.2 \times 10^{3}$ & $1 / 5$ & $2 / 5$ & $0 / 5$ & $0 / 5$ & $<5.0 \times 10^{2}$ \\
\hline & $\prime \prime$ & $+1.2 \times 10^{2}$ & $2 / 5$ & $3 / 5$ & $3 / 5$ & $0 / 5$ & $1.1 \times 10^{4}$ \\
\hline & & + HSS & $3 / 5$ & $2 / 5$ & $1 / 5$ & $0 / 5$ & $3.1 \times 10^{3}$ \\
\hline
\end{tabular}

* Numerator : Number of deaths among inoculated adult mice. Denominator: Total number inoculated.

\# Horse-serum saline.

interference did occur when the HNOP virus was given in an amount slightly more than CVS or approximately 100 times more than Flury virus.

\section{Discussion}

Rabies virus may be a highly neurotropic virus in a sense that it is quite reluctant in changing its organotropism in all kinds of laboratory attempts. Although it has a wide host range, preference for organs is confined mainly to nervous system. Even after adapted to growth in embryonated eggs, the highest concentration of virus was found without exception in embryonic brain (Koprowski and Cox, 1948), and this held true also in the case of infection of the 1-day egg (Yoshino et al., 1956a). The high egg passage (HEP) variation (Koprowski et al., 1954 ; Kuma, 1958) was accompanied by the loss of infectivity to adult mice, but this does not mean any change in organotropism, because the HEP viruses still were capable of infecting baby mice by intracerebral inoculation and, in infected embryonated eggs, again the highest viral concentration was observed in embryonic brain (Koprowski et al., 1954). Attempts to grow this virus on chorioallantois of the embryonated egg all failed, and no success has ever been attained in obtaining luxuriant growth of rabies virus in tissue culture not resorting to nervous tissues. 
Eagle and coworkers (1956) noted cytopathogenic effect of KB strain of human carcinoma cells after fairly massive infection with rabies virus but no virus was recovered in subculture. We also experienced a similar observation when fibroblastic outgrowth from minced mouse embryo brain was used in stationary tube cultures, in contrast to the data supplied by Bequignon et al. (1954). From the viewpoint that the egg-adapted strains, especially high egg passage (HEP) lines, seemed to be sufficiently avianized, we have tested previously on the possibility of the egg passaged Flury strain of propagating in tissue cultures employing various kinds of cells including outgrowth of minced chick embryo, but all the efforts were in vain to demonstrate any viral growth or cytopathogenic effects. These results of ours are in harmony with those of Deinhardt and Henle (1957) who eventually classified rabies virus as a non-growing, non-cytopathic virus for various tissue lines of human cells.

The egg-white-replaced 1-day egg (ERO) technique presented here, therefore, may be the only case in which rabies virus can grow in non-nervous cells with satisfactory consistency, provided that the ERO system is permitted to share the category of tissue culture. Of course, in this system too, there does exist a tiny embryo which possesses a small brain whose presence is hardly discernible macroscopically, but it is far from likely that a tissue of such a small size can play a predominant roll in supporting a marked degree of viral growth as revealed in our present data. Furthermore, viral growth in the ERO is evidently earlier than the differentiation of embryonic cells into a recognizable size of brain, and even after that this tiny brain is not exposed to outside but covered by other tissues. In fact, in the present ERO infection with rabies virus, the embryo itself seldom showed development of macroscopic level. Hence, there is a firm ground to believe that the growing blastodermal cells may be responsible for the observed growth of rabies virus in the ERO.

An advantage of this method is that the saline portion provides a viral suspension pure enough to be used as a source of vaccine or for any other purpose which requires sufficiently purified viral material. However, frankly, this method is by no means free of shortcomings. In the first place, the yolk sac, which is strong enough to stand comparatively drastic handling at the age of one day, becomes breakable during the incubation of ERO, especially in later stage. Secondly, what is more important from the practical viewpoint, the titer of saline virus obtained was not sufficiently high to fit the purpose of vaccine production. When we first attempted the present series of experiments, it was borne in mind to adapt these rabies virus strains through 1-day egg passage until finally they could yield a high titer of virus in the saline of ERO. Actually in the case of CVS strain, a slightly higher peak titer was reached by its 1-day egg-adapted line COP as compared with the mother strain CVS. However, with Flury strain, this was not the case. The only common observation was that the 1-day egg-adapted lines showed much faster growth than their respective mother strains. In the case of HEP rabies group, on the other hand, 1-day egg adaptation showed no appreciable merit when such comparison of growth curves was made, presumably because the HEP group viruses had already been avianized so highly that further 1-day egg passage did not induce such a marked change in growth rate in 1-day eggs as observed with the cases of CVS and of Flury strains. This interpretation is in harmony with that 
stated previously concerning the properties of the HEP rabies viruses (Kuma, 1958).

All these quantitative analyses are based on the conclusion given in the preceding paper (Kondo, 1958) that all rabies virus strains exhibit their titers in the baby mouse titration with equal efficiency, and consequently all titers expressed by other methods should be adjusted to the baby mouse infective units or its equivalent for the sake of comparison among different strains. On these premises, the fluid virus titer of ERO should be given a consideration as to whether or not it is high enough to be used for vaccine production.

It is generally accepted that, as a source of vaccine, an infected rabbit brain is desired to have the titer of at least $10^{-5.5}$ per $0.03 \mathrm{cc}$ by intracerebral inoculation of adult mice (Johnson, 1948). A brain of this titer, when made into a $5 \%$ suspension, will show the titer of $10^{-4.2}$, which means in our expression about $5 \times 10^{5} \mathrm{MIU}$ per cc, i.e. $10^{7} \mathrm{MIU}$ per $20 \mathrm{cc}$. But the peak concentration of the saline virus obtained with COP strain was approximately one log lower than this required level (Fig. 1). With the other strains tested, too, the peak titers of saline virus in terms of OIU were alike.

It is, of course, probable that in the saline containing no stabilizer for virus a considerable degree of viral degradation may have taken place, and therefore actual viral amount in it was higher than appears in Fig. 1. Furthermore, if a vaccine is prepared from the saline of ERO, one will be able to use it in a large dose without thinking of any undesirable side-effects. In addition, Kligler and Bernkopf (1941) stated that vaccine free of brain tissue components showed higher potency than expected from its original virus titer. Yet, it is our present feeling that much more refinements must be done before applying this technique to the practical vaccine production.

Aside from such practical uses, the ERO method furnished a new tool to study some theoretical aspects of host-virus interactions. Also in this application, however, a disadvantage lied in the way. That is to say, as the blastoderm grew even after massive viral infection, the number of cells available for virus to invade changed from hour to hour. Consequently, when we found the occurrence of interference in this system between two distinct strains, adult-mouse-pathogenic (CVS and Flury) and non-pathogenic (HEP groups), it was impossible to determine the time factor relating to this phenomenon. Some experiments were actually carried out in which the two strains were introduced with varying spacings of time, but the results were irregular. This inconsistency of results may reflect that the first and second inocula could not necessarily cover the same area of the blastoderm especially when the interval between the two injections was too long. Thus, there was no choice but that the two viruses were given simultaneously as a mixture.

The results showed that when more or less equal infective units of the two viruses were given no interference occurred, and this was true also when the viral amount was on a level nearly sufficient to infect all the entodermal cells at the time of infection. When a small amount of CVS or Flury virus was given together with a certain amount of HEP Flury-OP (HFOP) or HEP Nishigahara-OP (HNOP) virus, however, interference with the former virus by the latter was clearly demonstrated. With the present technique, very strict quantitative analyses can not be made owing to the reasons stated above, but a rough estimation might be possible, from the ratios of virus amounts which could cause interference, that the 
two HEP-OP viruses (HFOP and HNOP) possess about equal interfering capacity, and on the part of the viruses to be interfered the CVS strain is more readily interfered by them than the Flury strain.

All these facts seem to point out that each cell reproduces progeny of the virus of first arrival and rejects any virus subsequently reaching it, because otherwise the HEP viruses would have suppressed CVS or Flury virus when given in similar amounts due to the different growth velocities within the 1-day egg's blastodermal cells. In other words, the interference observed here can not be interpreted as such that the HEP viruses won competition with CVS or Flury virus within cells pre-occupied by the latter. This conclusion might have been consolidated by reciprocal interference experiments, but unfortunately it was impossible to test the possibility of reciprocity of interference, since the adult mouse-pathogenic strains were not entirely non-pathogenic for 1-day eggs.

The failure to demonstrate in adult mouse brains occurrence of interference between the HEP Flury and rodent-fixed strains in the hands of Koprowski et al. (1954) may not be incompatible with the present results. On the assumption that their HEP Flury virus had properties similar to our present HEP Nishigahara (Kuma, 1958), it may be presumable that the growth of their HEP Flury virus in the adult mouse brain was too poor and varied greatly among individual mice and as a consequence left many brain cells freely available for any rodent-fixed virus which could multiply therein much faster. Actually, Koprowski et al. (1954) could demonstrate interference with the early egg passage of Flury by the HEP Flury virus in adult mouse brain. Thus, the occurrence of interference between any combination of two strains depends on the host in which it is tested as well as on the quantitative relation between viruses and cells. With this concept in mind, attention must be called to the possibility that, although our present data showed occurrence of interference with mouse-fixed CVS and with egg-adapted Flury strains by the HEP rabies viruses, such an interference can not be expected to take place in a human body. Future experiments in animals are desired to ascertain whether this is true or not.

\section{SUMMARY}

The egg-white-replaced 1-day egg (ERO) technique, which was previously established in the study of herpes simplex virus, was applied to rabies virus. Four mother strains, mouse-fixed CVS, egg-adapted Flury, HEP (high egg passage) Flury, and HEP Nishigahara, and their 1-day egg passage lines were all grown by this method, thereby releasing considerable amounts of virus into the saline portion. After infection, the blastodermal cells grew continuously while the embryonic development was markedly restricted. The saline virus amounts were about one $\log$ lower than the yolk virus. Growth of the 1-day egg-adapted viruses was faster than their respective mother strains, especially in the case of COP (1-day eggadapted CVS) and of FOP (1-day egg-adapted Flury); the peak titers were alike among them when compared on the ground that the baby mouse infective unit is an equivalent among all the strains, but in the case of COP virus its peak titers seemed to be slightly higher than those of its mother strain CVS.

When adult-mouse-pathogenic virus (CVS or Flury) was given combinedly with 
non-pathogenic virus (HEP group), interference by the latter, as evidenced by the absence of adult-mouse-pathogenic virus in the saline of ERO, was observed depending on the ratio of inoculated virus amounts. Such an interference took place only when the HEP virus exceeded in amount the CVS or Flury virus; the CVS strain seemed to be more readily interfered with than was the Flury strain in the ERO system.

\section{REFERENCES}

Bequignon, M. R., Gruest, J., Vialat, C. \& Vienchange, J. (1954) : Culture du virus rabique in vitro. Comp. Rend. Acad. Sc., 239, 1162-1164.

BERNKOPF, H. \& KLIGLER, I. J. (1937) : The cultivation of rabies virus in tissue culture. Brit. J. Exper. Path., 18, 481-485.

DEINHARDT, F. \& HENLE, G. (1957): Studies on the viral spectra of tissue lines of human cells. J. Immunol., 79, 60-67.

EAgle, H., Habel, K., Rowe, W. P. \& HuEbneR, R. J. (1956) : Viral susceptibility of a human carcinoma cell (strain KB). Proc. Soc. Exper. Biol. \& Med., 91, 361-364.

Johnson, H. N. (1948) : In Viral and Rickettsial Diseases of Man, Philadelphia, U. S. A., p. 225.

KANAZAWA, K. (1936): Sur la culture in vitro du virus de la rage. Jap. J. Exper. Med., $14,519-522$.

KLIGLER, I. J. \& BERNKOPF, H. (1938): Studies on antirabic immunization with formalized culture virus. Brit. J. Exper. Path., 19, 378-383.

KLIGLER, I. J. \& BERNKOPF, H. (1941) : Studies on the cultivation and antigenic characters of rabies virus. Am. J. Hyg., 33, Sec. B. 1-8.

KONDO, A. (1958): Infection of the one-day old fertile hen's egg with rabies virus IV. A quantitative analysis of infective units for mice (MIU) and for one-day eggs (OIU). Jap. J. M. Sc. \& Biol., 11, 45-57.

KoprowsKI, H., BLACK, J. \& NELSEN, D. J. (1954): Studies on chick-embryo-adapted-rabies virus VI. Further changes in pathogenic properties following prolonged cultivation in the developing chick embryo. J. Immunol., 72, 94-106.

KopROWSKI, H. \& Cox, H. R. (1948): Studies on chick-embryo-adapted-rabies virus I. Culture characteristics and pathogenicity. J. Immunol., 60, 533-554.

KUMA, N. (1958) : Infection of the one-day old fertile hen's egg with rabies virus III. Some observaions on high egg passage (HEP) strains. Jap. J. M. Sc. \& Biol., 11,31-43.

PARKER, R. C. \& Hollender, A. J. (1945): Propagation of rabies virus in tissue culture. Proc. Soc. Exper. Biol. \& Med., 60, 94-98.

Plotz, H. \& REAGAN, R. (1942) : In vitro cultivation of the street virus of rabies. Science, 95, $102-104$.

Schultz, E. W. \& Williams, G. F. (1937-8) : Cultivation of rabies virus. Proc. Soc. Exper. Biol. \& Med., 37, 372-373.

Vienchange, J., Vialat, C., Gruest, J. \& Bequignon, R. (1956) : Essais de culture in vitro du virus rabique des rues. Ann. Inst. Pasteur, 90, 361-363.

WEBSTER, L. T. (1937) : Propagation of rabies virus in tissue culture. J. Exp. Med., 66, $125-131$.

WEBSTER, L. T. (1938) : Experiments on antirabic vaccination with tissue culture virus. Am. J. Public Health, 28, 44-46.

WeBster, L. T. \& Clow, A. D. (1936): Propagation of rabies virus in tissue culture and the successful use of culture virus as an antirabic vaccine. Science, 84, 487-488.

YoSHINO, K. (1956): Infection of one-day old fertile hen's egg with herpes simplex virus. J. Immunol.. 76, 301--307. 
Yoshino, K., KumA, N., Kondo, A. \& KitAOKA, M. (1956 a) : Infection of the one-day old fertile hen's egg with rabies virus I. Growth curves and serial passages. Jap. J. M. Sc., \& Biol., 9, 259-271.

Yoshino, K., Kondo, A., KumA, N. \& KiTAOKA, M. (1956 b) : Infection of the one-day old fertile hen's egg with rabies virus II. Applicatlon to rapid viral titration and neutralization test. Ja.p. J. M. Sc. \& Biol., 9, 273-282.

Yoshino, K. \& TANJGUCHI, H. (1957): Further studies on the growth of herpes simplex virus in the egg-white-replaced one-day egg. Jap. J. M. Sc. \& Biol., 10, 257-275. 